langages, information, médiations

\title{
...Nous avons reçu... David Forest : Abécadaire de la société de surveillance, Éditions Syllepse, 2009
}

\section{CpenEdition}

Journals

Édition électronique

URL : http://journals.openedition.org/edc/1866

DOI : 10.4000/edc. 1866

ISSN : 2101-0366

Éditeur

Université de Lille

\section{Édition imprimée}

Date de publication : 1 juin 2010

Pagination : 207

ISBN : 978-2-917562-03-1

ISSN : $1270-6841$

Référence électronique

"...Nous avons reçu... David Forest : Abécadaire de la société de surveillance, Éditions Syllepse, 2009 », Études de communication [En ligne], 34 | 2010, mis en ligne le 14 septembre 2010, consulté le 22

septembre 2020. URL : http://journals.openedition.org/edc/1866 ; DOI : https://doi.org/10.4000/edc 1866

Ce document a été généré automatiquement le 22 septembre 2020.

(c) Tous droits réservés 
...Nous avons reçu... David Forest : Abécadaire de la société de surveillance, Éditions Syllepse, 2009

L'auteur est avocat spécialisé dans les technologies de l'information et docteur en sciences politiques. Cet ouvrage de 135 pages (petit format, $10,5 \times 16,5$ ) introduit la partie abécédaire par un texte très engagé et qui remet en cause «la confiance inquiétante accordée aux systèmes d'information ». On aurait tort de croire qu'il s'agit là d'un ouvrage proposant des définitions. L'ouvrage part du principe que surveiller c'est punir. Chaque article recherche en effet les causes et les logiques de l'objet ou entité décrit ou de l'utilisation qui en est fait dans une société dite " de surveillance " plus que d'information. Au panorama des «technologies » règlementées qui empiètent notre espace et se fondent dans notre quotidien: l'ADN (test), la biométrie, la cybersurveillance, les moteurs de recherche etc. D'autres entrées (CNIL, éthique, piratage, peur) proposent une réflexion documentée sur l'histoire et les méthodes de «régulation ». Des références bibliographiques très diverses (notamment travaux de recherche, articles de presse et documents techniques) sont proposées. 